\title{
Influence of Dietary Non-phytate Phosphorous Levels and Phytase Supplementation on the Performance and Bone Characteristics of Broilers
}

\section{author(s)}

Karimi A

Bedford MR

Sadeghi Gh

Ghobadi Z

University of Kurdistan

\section{Mail Adress}

\section{A Karimi}

Department of Animal Science

Faculty of Agriculture

University of Kurdistan

Sanandaj, 66177-14381

Kurdistan, IRAN.

E-mail: Akarimi@uok.ac.ir

\section{EKeywords}

Bone ash, broiler, phosphorous, phytate, phytase.

\section{acknowledgements}

The authors wish to express thanks to the University of Kurdistan for funding this research project.
Submitted: September/2010

Approved: January/2011

\begin{abstract}
Precise phosphorus nutrition is important for significant reductions in both $\mathrm{P}$ pollution and ration costs. The influence of different levels (\%) of dietary nPP fed from 0 to $20 \mathrm{~d}(0.45,0.40,0.35,0.30,0.25$, compared with feeding $0.20 \mathrm{nPP}$ with and without 500 F.T.U. of phytase per $\mathrm{kg}$ of diet) and from 21 to $36 \mathrm{~d}$ of age $(0.414,0.364$, $0.314,0.264,0.214$, compared with $0.164 \mathrm{nPP}$ with and without 500 F.T.U. of phytase per $\mathrm{kg}$ of diet) were evaluate using a total of 588 day-old commercial broiler chicks. Each treatment was replicated four times in a completely randomized design. Body weight (BW), daily gain $(D G)$, feed intake (DFI), feed conversion ratio, plasma $P$ level and bone characteristics were determined, and from these data the P equivalency of the phytase was estimated. Feeding diets containing less than $0.40 \%$ of $\mathrm{nPP}$ to birds between 0 and $20 \mathrm{~d}$ resulted in inferior BW, $\mathrm{DFI}$, plasma P level and bone characteristics compared with the control. However, optimum FCR and mortality was supported at lower levels of nPP (0.25\%). Between 21 and 36 d, 0.364\% was enough to optimise BW, DFI, and femur ash (\%); whilst only $0.314 \%$ or greater was needed to support optimum DG, toe and tibia ash and only 0.214 to $0.264 \%$ was required to optimise shank, femur and tibia lengths; FCR and survivability. A broken line analysis also showed that the nPP (\%) requirement ranged from 0.267 to 0.410 and 0.272 to $0.380 \%$ during 0 to 20 and 21 to $36 \mathrm{~d}$, respectively. Phytase supplementation improved performance and bone criterion and its $P$ equivalency, depending upon the response of interest and birds age, ranged from 0.00 to $0.110 \%$. In conclusion, the results showed that the combination of a lower level of $\mathrm{nPP}$ and phytase may be used to increase dietary P utilization, without severe changes in performance and bone quality.
\end{abstract}

\section{INTRODUCTION}

Phosphorus $(P)$ is one of the most important and expensive macro minerals required by poultry and plays a vital role in the development and maintenance of the skeletal system and in numerous biochemical reactions in the body. The role of phosphorus and determination of its requirement in broiler nutrition has received a great deal of attention, and continues to do so, especially in the context of pollution from phosphorus run-off from agricultural operations (Waldroup, 1999; Bedford, 2000; Kies et al., 2001; Adeola \& Sands, 2003). An important aspect of phosphorus nutrition is the digestibility of phytate phosphorus, a form of phosphorus that naturally occurs in feedstuffs of plant origin. In legumes and grains, phytate phosphorus represents about 50 to 75 percent of the total phosphorus content. Swine and chickens lack sufficient endogenous phytase to meaningfully digest the phosphorylated cyclic sugar alcohols, or phytate, present in their 
feed (Bedford, 2000; Adeola \& Sands, 2003; Selle et al., 2006).

The poor utilization of phytin-bound $P$ by monogastric animals and its consequences on diet cost, the environment, and digestibility of minerals and protein have lead to extensive research efforts to understand the process of phytic acid digestion (Bedford, 2000; Kies et al., 2001; Adeola \& Sands, 2003; Powell et al., 2008). During the last decade, several alternative methods for reducing the aforementioned negative impacts of phytate $\mathrm{P}$ on the environment and poultry performance have been recommended. Feeding birds with diets formulated closer to their nPP requirements, coupled with use of microbial phytase, are among the most successful strategies that have attracted scientific and practical attention (Simons et al., 1990; N.R.C, 1994; Summers, 1997; Sohail \& Roland, 1999; Waldroup, 1999). It has been shown that the supplementation of poultry diets with phytase increases trace mineral absorption and amino acid digestibility, and reduces the amount of phosphorus in the manure. The extent of the observed effects, however, will depend on diet type (i.e., main cereals/oilseed meals), phytase inclusion rate, degree of inorganic phosphorus replacement, and dietary phosphorus content relative to the animal needs (Correl, 1999; Waldroup, 1999; Bedford, 2000; Kies et al., 2001; Adeola \& Sands, 2003; Yan \& Waldroup, 2006; Olukosi et al., 2007, 2008). With regards to the effect of dietary phosphorus, researchers have found that lower concentrations of dietary phosphorus tend to increase the utilization of phytate phosphorus (Kilburn \& Edwards, 2001) even in the absence of phytase.

The first objective of this study was to evaluate the influence of dietary nPP level on the performance and bone length and mineralization of broilers. The second objective was to estimate inorganic $P$ equivalency of phytase considering different performance and bone criteria as dependent variables.

\section{MATERIALS AND METHODS}

\section{Birds, housing and management}

Five hundred and eighty eight one-day-old Ross ${ }^{\circledR}$ 308 broiler chicks (mixed sex) were used in a 36-day trial. Chicks were housed in 28 floor pens $(1.25 \times 1.4 \mathrm{~m})$, with wood shavings used as litter, throughout the experiment. Lighting was continuous for the first day post hatching, after which a 23L: 1D schedule was maintained for the duration of the experiment.
Temperature was maintained between 30 and $32^{\circ} \mathrm{C}$ at the beginning of the rearing period and was gradually decreased by 2 to $3^{\circ} \mathrm{C}$ each week to a final temperature of $22^{\circ} \mathrm{C}$ at the end of rearing period. Chicks were given free access to the mash diets and to water during the experimental period. Care and management of the chicks were in accordance with commercial guidelines and were approved by University of Kurdistan Animal Ethics Committee.

\section{Treatments and experimental design}

Seven treatments were applied with different nPP concentrations (\%), with the lowest nPP level being offered with or without microbial phytase at 500 F.T.U./ $\mathrm{kg}$ feed. Each experimental treatment was replicated four times and each replicate pen contained 21 chicks in a completely randomized experimental design.

\section{Nutritional composition of the diets}

The corn-soybean meal-based starter diets were formulated to meet or exceed the requirements (NRC, 1994) for all nutrients, with the exception of nPP (Tables 1 and 2). Experimental diets formulated to contain different nPP levels (\%) during 0 to $20 \mathrm{~d}(0.450$, $0.400,0.350,0.300,0.250,0.200$, and $0.200+500$ F.T.U. $\mathrm{kg}^{-1}$ of phytase $\left.{ }^{*}\right)$ and 21 to $36 \mathrm{~d}(0.414,0.364$, $0.314,0.264,0.214,0.164$, and $0.164+500$ F.T.U. $\mathrm{kg}^{-1}$ of phytase). Basal diets were formulated to be isonitrogenous and isocaloric (Tables 1 and 2). The nutritional contents of the dietary ingredients were estimated from the feed composition tables of the National Research Council (1994); however, P and Ca contents in $\mathrm{CaCO}_{3}$ and DCP were measured by the supplier. The microbial phytase (EC 3.1.3.8; 10000 $\mathrm{Ug}^{-1}$, one unit of phytase activity is defined as the quantity of enzyme required to produce $1 \mu \mathrm{mol}$ of inorganic $\mathrm{P} / \mathrm{min}$ from $5.1 \mathrm{mmol} / \mathrm{L}$ of sodium phytate at a pH of 5.5 and a temperature of $37^{\circ} \mathrm{C}$ ) used in this study was an Aspergillus niger product (Natuphos, BASF) obtained from Vetaque company (BASF product distributor), P.O. Box 14655/ 174, Tehran, IRAN.

\section{Parameters}

Birds were weighed as a group on arrival and at 20 and 36 days of age on a pen basis. Feed intake recorded at 20 and 36 days. Feed conversion ratio (FCR) was calculated as feed intake/weight gain. Mortality was daily recorded and feed intake data

\footnotetext{
* Natuphos, BASF Aktiengesellschaft Strategic Marketing Animal Nutrition, 67056 Ludwigshafen, Germany
} 
Table 1 - Composition (g/kg) and calculated analysis of starter diets (1-20d)

\begin{tabular}{|c|c|c|c|c|c|c|c|}
\hline & \multicolumn{7}{|c|}{ Dietary NPP Levels $(\mathrm{g} / \mathrm{kg})$} \\
\hline & 2.0 & 2.0 & 2.5 & 3.0 & 3.5 & 4.0 & 4.5 \\
\hline Phytase $^{1}(\mathrm{FTU} / \mathrm{kg}$ ) & 500 & 0 & 0 & 0 & 0 & 0 & 0 \\
\hline Ingredients & \multicolumn{7}{|c|}{$\left(\mathrm{g} \mathrm{kg}^{-1}\right)$} \\
\hline Corn grain & 566.6 & 566.6 & 566.6 & 566.6 & 566.6 & 566.6 & 566.6 \\
\hline SBM $\left(440 \mathrm{~g} \mathrm{~kg}^{-1} \mathrm{CP}\right)$ & 368.0 & 368.0 & 368.0 & 368.0 & 368.0 & 368.0 & 368.0 \\
\hline Fish meal $\left(630 \mathrm{~g} \mathrm{~kg}^{-1} \mathrm{CP}\right)$ & 15.0 & 15.0 & 15.0 & 15.0 & 15.0 & 15.0 & 15.0 \\
\hline Soy oil & 14.9 & 14.9 & 14.9 & 14.9 & 14.9 & 14.9 & 14.9 \\
\hline $\mathrm{CaCO}_{3}$ & 19.6 & 19.6 & 17.8 & 16.0 & 14.2 & 12.4 & 10.7 \\
\hline D.C.P2 & 0.00 & 0.00 & 3.0 & 5.9 & 8.9 & 11.8 & 14.8 \\
\hline Washed sand & 5.8 & 5.8 & 4.6 & 3.5 & 2.3 & 1.2 & 0.00 \\
\hline Common Salt & 3.0 & 3.0 & 3.0 & 3.0 & 3.0 & 3.0 & 3.0 \\
\hline Mineral premix ${ }^{3}$ & 2.5 & 2.5 & 2.5 & 2.5 & 2.5 & 2.5 & 2.5 \\
\hline Vitamin Premix ${ }^{4}$ & 2.5 & 2.5 & 2.5 & 2.5 & 2.5 & 2.5 & 2.5 \\
\hline DL. Methionine & 1.6 & 1.6 & 1.6 & 1.6 & 1.6 & 1.6 & 1.6 \\
\hline $\begin{array}{l}\text { L-Lysine } \mathrm{HCL} \\
\end{array}$ & 0.6 & 0.6 & 0.6 & 0.6 & 0.6 & 0.6 & 0.6 \\
\hline \multicolumn{8}{|c|}{ Calculated nutrient composition ( $\mathrm{g} / \mathrm{kg})$} \\
\hline ME (MJKg) & 12.14 & 12.14 & 12.14 & 12.14 & 12.14 & 12.14 & 12.14 \\
\hline $\mathrm{CP}$ & 222.3 & 222.3 & 222.3 & 222.3 & 222.3 & 222.3 & 222.3 \\
\hline$\overline{C A}$ & 9.4 & 9.4 & 9.4 & 9.4 & 9.4 & 9.4 & 9.4 \\
\hline Total Phosphorus & 4.4 & 4.4 & 4.9 & 5.4 & 5.9 & 6.4 & 6.9 \\
\hline Non-Phytate Phosphorus & 2.0 & 2.0 & 2.5 & 3.0 & 3.5 & 4.0 & 4.5 \\
\hline Methionine & 5.4 & 5.4 & 5.4 & 5.4 & 5.4 & 5.4 & 5.4 \\
\hline TSAA & 8.9 & 8.9 & 8.9 & 8.9 & 8.9 & 8.9 & 8.9 \\
\hline Lysine & 13.3 & 13.3 & 13.3 & 13.3 & 13.3 & 13.3 & 13.3 \\
\hline $\mathrm{Na}$ & 1.5 & 1.5 & 1.5 & 1.5 & 1.5 & 1.5 & 1.5 \\
\hline \multicolumn{8}{|c|}{$\begin{array}{l}\text { 1 - Natuphos, } 10000 \text { F.T.U. /g , BASF Aktiengesellschaft Strategic Marketing Animal Nutrition, } 67056 \text { Ludwigshafen, Germany. } 2 \text { - Contain } 250 \mathrm{~g} \mathrm{~kg}{ }^{-1} \text { Ca } \\
\text { and } 180 \text { g kg-1 P. } 3 \text { - Provides per kg of diet: Vit. A, } 9000 \text { I.U.; Vit. D3, } 2000 \text { I.U.; Vit. E, } 18 \text { I.U.; Menadion, } 2 \text { mg; Thiamine, } 1.8 \text { mg; Riboflavin, } 6.6 \text { mg; } \\
\text { Niacin, } 30 \text { mg; Pyridoxine, } 3 \text { mg; Vit B12, } 15 \text { mcg; D-Pantothenic acid, 100. mg; Folic acid, } 1 \text { mg; Biotin , } 0.1 \text { mg; Choline chloride, 500mg; Antioxidant, } \\
100 \text { mg. } 4 \text { - Provides per Kg of diet: Manganese, } 100 \text { mg; Zinc, } 84.7 \text { mg; Iron, } 50 \text { mg; Copper, } 10 \text { mg; lodine, } 1 \text { mg; Se, } 0.2 \text { mg. }\end{array}$} \\
\hline
\end{tabular}

\begin{tabular}{|c|c|c|c|c|c|c|c|}
\hline 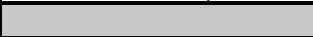 & \multicolumn{7}{|c|}{ Dietary NPP Levels $(\mathrm{g} / \mathrm{kg})$} \\
\hline Phytase $^{1}(\mathrm{FTU} / \mathrm{kg})$ & 1.64 & 1.64 & 2.14 & 2.64 & 3.14 & 3.64 & 4.14 \\
\hline \begin{tabular}{|l} 
Ingredients \\
\end{tabular} & 500 & 0 & 0 & 0 & 0 & 0 & 0 \\
\hline Corn grain & \multicolumn{7}{|c|}{$\left(\mathrm{g} \mathrm{kg}^{-1}\right)$} \\
\hline SBM $\left(440 \mathrm{~g} \mathrm{~kg}^{-1}\right.$ CP) & 603.3 & 603.3 & 603.3 & 603.3 & 603.3 & 603.3 & 603.3 \\
\hline Fish meal $\left(630 \mathrm{~g} \mathrm{~kg}^{-1} \mathrm{CP}\right)$ & 330.8 & 330.8 & 330.8 & 330.8 & 330.8 & 330.8 & 330.8 \\
\hline Soy oil & 5.0 & 5.0 & 5.0 & 5.0 & 5.0 & 5.0 & 5.0 \\
\hline $\mathrm{CaCO}_{2}$ & 24.7 & 24.7 & 24.7 & 24.7 & 24.7 & 24.7 & 24.8 \\
\hline D.C.P $P^{2}$ & 19.6 & 19.6 & 17.8 & 16.1 & 14.3 & 12.5 & 10.7 \\
\hline Washed sand & 0.00 & 0.00 & 2.9 & 5.9 & 8.8 & 11.8 & 14.8 \\
\hline Common Salt & 5.9 & 5.9 & 4.7 & 3.6 & 2.4 & 1.2 & 0.00 \\
\hline Mineral premix ${ }^{3}$ & 3.1 & 3.1 & 3.1 & 3.1 & 3.1 & 3.1 & 3.1 \\
\hline Vitamin Premix ${ }^{4}$ & 2.5 & 2.5 & 2.5 & 2.5 & 2.5 & 2.5 & 2.5 \\
\hline DL. Methionine & 2.5 & 2.5 & 2.5 & 2.5 & 2.5 & 2.5 & 2.5 \\
\hline \multirow{2}{*}{ L-Lysine $\mathrm{HCL}$} & 1.9 & 1.9 & 1.9 & 1.9 & 1.9 & 1.9 & 1.9 \\
\hline & 0.7 & 0.7 & 0.7 & 0.7 & 0.7 & 0.7 & 0.7 \\
\hline \multicolumn{8}{|c|}{ Calculated nutrient composition $(\mathrm{g} / \mathrm{kg})$} \\
\hline $\mathrm{ME}(\mathrm{KJ} \mathrm{Jg})$ & 12.56 & 12.56 & 12.56 & 12.56 & 12.56 & 12.56 & 12.56 \\
\hline$C P$ & 203.4 & 203.4 & 203.4 & 203.4 & 203.4 & 203.4 & 203.4 \\
\hline $\mathrm{Ca}$ & 8.8 & 8.8 & 8.8 & 8.8 & 8.8 & 8.8 & 8.8 \\
\hline Total Phosphorus & 3.98 & 3.98 & 4.48 & 4.98 & 5.48 & 5.98 & 6.48 \\
\hline Non-Phytate Phosphorus & 1.64 & 1.64 & 2.14 & 2.64 & 3.14 & 3.64 & 4.14 \\
\hline Methionine & 5.3 & 5.3 & 5.3 & 5.3 & 5.3 & 5.3 & 5.3 \\
\hline TSAA & 8.0 & 8.0 & 8.5 & 8.5 & 8.5 & 8.5 & 8.5 \\
\hline Lysine & 11.9 & 11.9 & 11.9 & 11.9 & 11.9 & 11.9 & 11.9 \\
\hline $\mathrm{Na}$ & 1.5 & 1.5 & 1.5 & 1.5 & 1.5 & 1.5 & 1.5 \\
\hline \multicolumn{8}{|c|}{$\begin{array}{l}\text { - Natuphos, } 10000 \text { F.T.U. /g , BASF Aktiengesellschaft Strategic Marketing Animal Nutrition, } 67056 \text { Ludwigshafen, Germany. } 2 \text { - Contain } 250 \text { g kg-1 Ca } \\
\text { and } 180 \text { g kg-1 P. } 3 \text { - Provides per kg of diet: Vit. A, } 9000 \text { I.U.; Vit. D3, } 2000 \text { I.U.; Vit. E, } 18 \text { I.U.; Menadion, } 2 \text { mg; Thiamine, } 1.8 \text { mg; Riboflavin, } 6.6 \text { mg; } \\
\text { Niacin, } 30 \text { mg; Pyridoxine, } 3 \text { mg; Vit B12, } 15 \text { mcg; D-Pantothenic acid, 100. mg; Folic acid, 1 mg; Biotin , } 0.1 \text { mg; Choline chloride, 500mg; Antioxidant, } \\
100 \text { mg. } 4 \text { - Provides per Kg of diet: Manganese, } 100 \text { mg; Zinc, } 84.7 \text { mg; Iron, } 50 \text { mg; Copper, } 10 \text { mg; lodine, } 1 \text { mg; Se, } 0.2 \text { mg. }\end{array}$} \\
\hline
\end{tabular}


were corrected for body weight of dead birds. Average body weight (BW), daily gain (DG), daily feed intake $(D F I)$, and FCR were determined for each period and for the overall experiment. At the age of 20 and 36 days, four birds from each treatment, each as close to the pen average weight as possible, were selected for bone measurements. Birds were weighed, killed by cervical dislocation, and the whole left leg (including femur, tibia, shank) from each of the chicks was excised and defleshed without boiling. Legs were individually sealed in plastic bags to minimize moisture loss, and stored at $-20{ }^{\circ} \mathrm{C}$ until analysis. Legs were thawed before bone characteristics were determined. The femur, tibia and shank of each leg were excised by making a cut at the adjacent anterior and posterior joints. Femur, tibia and shank length was measured with a calliper with an accuracy of $0.001 \mathrm{~cm}$. After removing the fat by extraction (femurs and tibias) in refluxing petroleum ether in a Soxhlet apparatus and drying at $105^{\circ} \mathrm{C}$ until a consistent weight was obtained, bone ash was determined by ashing in tarred ceramic crucibles for $12 \mathrm{~h}$ at $605{ }^{\circ} \mathrm{C}$ (AOAC,1990). The ash content was expressed as grams of ash per 100 grams of the defatted dry weight. The middle toe ash content was also determined at $36 \mathrm{~d}$ following the procedure above; but without defatting.

On 20d, blood samples were taken from four birds per dietary treatment to determine the phosphorus level of plasma, using an enzymatic kit produced by Zist Chimie Company (Tehran, Iran).

\section{Statistical analysis}

Pen average was used as the experimental unit for statistical analysis. Data were analyzed according to the General Linear Models (GLM) procedure of SAS statistical package (SAS institute, 1991) as a completely randomized experimental design. Mortality data were transformed to $\sqrt{x+1}$ prior to analysis. Significant differences among treatments were determined at $p<0.05$ using Duncan's new multiple range tests. In addition, nonlinear regression analysis was conducted to estimate nPP levels (inflection points) required for maximum performance parameters and bone characteristics using the PROC NLIN procedure of SAS (SAS Institute Inc., 1991), incorporating the SAS macro of Robbins (1979, 1986). Linear ( $Y=a+b x)$, logarithmic $(Y=a+\ln (x))$ and quadratic $\left(Y=a x^{2}+b x+c\right)$ equations were derived from $\mathrm{nPP}(\%)$ concentration ( $\mathrm{x}$ as independent variable) and the variables of interest ( $Y$ as dependent variable). These equations were solved to calculate optimal nPP concentrations and P equivalency values of the phytase. The relationship between nPP level and performance and bone characteristics was studied using the CORR procedure of SAS (SAS institute, 1991).

\section{RESULTS AND DISCUSSION}

\section{Effect of nPP level}

The results of the experiment are summarized in Tables 3 to 9.

\section{Starter period (0 to $\mathbf{2 0} \mathrm{d}$ )}

BW, DG, DFI, and plasma P level were significantly $(p<0.05)$ reduced when diets containing less than 0.40 $\%$ nPP were offered (Table 3). FCR, on the other hand, significantly $(p<0.05)$ deteriorated only when dietary nPP level was lower than $0.30 \%$, whilst mortality increased only when nPP levels were as low as $0.2 \%$. Feeding the $0.20 \%$ nPP diet had severe negative impacts on all assessed performance parameters.

Bone ash content and length was also significantly affected by reducing dietary nPP levels during the 0 to $20 \mathrm{~d}$ period (Table 3). Tibia and femur ash content (\%) deteriorated when dietary nPP was reduced below $0.40 \%$. The length of different parts of the leg, including shank, tibia and femur, was also reduced $(p<0.05)$ when dietary nPP level was reduced. The femur (optimal nPP level not lower than $0.45 \%$ ) was more sensitive than the shank $(0.40 \%$ or more required), which in turn was more sensitive than the tibia $(0.35 \%)$.

Non-linear regression analysis (Table 8) showed that while 0.38 to $0.40 \% \mathrm{nPP}$ was sufficient to support most performance parameters between 0 and $20 \mathrm{~d}$, higher nPP levels (>0.41\%) were needed to maintain bone ash content and length. Pearson correlation analysis (Table 6) also demonstrated a highly positive correlation between dietary nPP level and most performance and bone parameters, while significant negative correlations were observed between dietary nPP level and feed conversion ratio and mortality rate during this period.

\section{Grower period (21-36 d)}

BW and DFI were significantly $(p<0.05)$ decreased when dietary nPP was reduced to less than $0.364 \%$ (Table 4), which was considerably more nPP than required to maintain DG $(0.314 \%)$; FCR $(0.214 \%)$, and bird survival $(0.264 \%)$. It is important to note, however, that BW data are a composite of the growth rate during the $0-20$ and $20-36$ day periods, whereas all other parameters were exclusive to the 20-36 period. 
Table 3 - Effect of nPP levels and phytase supplementation on performance and bone characteristics of broiler chicks from 0 to $20 \mathrm{~d}$ fed corn-soybean meal based diet.

\begin{tabular}{|c|c|c|c|c|c|c|c|c|c|c|c|c|}
\hline \multirow[t]{2}{*}{ NPP (\%) } & \multirow{2}{*}{$\begin{array}{l}\text { Phytase } \\
\text { (F.T.U./kg) }\end{array}$} & \multirow{2}{*}{$\begin{array}{l}\text { BW, g } \\
(20 \text { d) }\end{array}$} & \multirow{2}{*}{$\begin{array}{c}\text { DG, } \\
\text { g }\end{array}$} & \multirow{2}{*}{$\begin{array}{c}\text { DFI, } \\
\text { g }\end{array}$} & \multirow{2}{*}{$\begin{array}{l}\text { FCR, } \\
(g / g)\end{array}$} & \multirow{2}{*}{$\begin{array}{l}\text { Plasma } \\
\text { P level }\end{array}$} & \multirow{2}{*}{$\begin{array}{l}\text { Shank length } \\
(\mathrm{mm})\end{array}$} & \multicolumn{2}{|c|}{ Tibia } & \multicolumn{2}{|c|}{ Femur } & \multirow[b]{2}{*}{$\begin{array}{l}\text { Mort. } \\
(\%)\end{array}$} \\
\hline & & & & & & & & $\begin{array}{l}\text { Length } \\
(\mathrm{mm})\end{array}$ & $\begin{array}{l}\text { Ash } \\
(\%)\end{array}$ & $\begin{array}{c}\text { Length } \\
(\mathrm{mm})\end{array}$ & $\begin{array}{l}\text { Ash } \\
(\%)\end{array}$ & \\
\hline 0.45 & 0 & $605 a$ & $28.5 a$ & $48.6 a$ & $1.71 \mathrm{c}$ & $6.90 a$ & $54.5 a$ & $68.8 a$ & $36.5 a$ & $53.5 a$ & $38.2 \mathrm{a}$ & $6.0 \mathrm{~b}$ \\
\hline 0.40 & & $632 a$ & $29.6 a$ & $50.1 a$ & $1.70 c$ & $5.79 a b$ & 53.6ab & $67.1 \mathrm{ab}$ & $36.6 a$ & $50.8 b$ & $34.0 \mathrm{ab}$ & $7.1 b$ \\
\hline 0.35 & & $557 b$ & $26.1 \mathrm{~b}$ & $44.1 \mathrm{~b}$ & $1.69 \mathrm{c}$ & $5.27 \mathrm{~b}$ & $52.3 b c$ & $66.1 \mathrm{abc}$ & $33.8 \mathrm{~b}$ & $50.6 b$ & $31.58 \mathrm{bc}$ & $6.0 \mathrm{~b}$ \\
\hline 0.30 & & $498 c$ & $23.2 c$ & $40.6 b c$ & $1.75 c$ & $4.68 \mathrm{~b}$ & $51.6 b c$ & $64.3 \mathrm{bcd}$ & $29.3 d c$ & $47.9 c$ & $26.9 d c$ & $4.8 \mathrm{~b}$ \\
\hline 0.25 & & $415 d$ & $18.9 d$ & $41.1 \mathrm{bc}$ & $2.18 \mathrm{~b}$ & $4.53 b$ & $51.8 b c$ & $63.2 \mathrm{cde}$ & $30.1 \mathrm{c}$ & $46.6 c$ & $25.8 d$ & $7.1 \mathrm{~b}$ \\
\hline 0.20 & & $312 \mathrm{e}$ & $13.0 \mathrm{e}$ & $37.3 c$ & $2.54 a$ & $4.51 b$ & $48.7 d$ & $61.0 \mathrm{e}$ & $26.7 d$ & $43.9 d$ & $22.7 d$ & $25.0 a$ \\
\hline 0.20 & 500 & $428 d$ & $19.2 d$ & $42.3 b$ & $2.21 \mathrm{~b}$ & $4.92 b$ & $50.6 \mathrm{dc}$ & 62.7ed & $28.6 \mathrm{dc}$ & $45.8 \mathrm{dc}$ & $26.1 d$ & $9.5 b$ \\
\hline $\mathrm{P}$-value & & 0.0001 & 0.0001 & 0.0001 & 0.0001 & 0.0141 & 0.0004 & 0.0002 & 0.0001 & 0.0001 & 0.0001 & 0.0001 \\
\hline SEM & & 13.016 & 0.570 & 1.431 & 0.057 & 0.461 & 0.729 & 0.982 & 1.026 & 0.828 & 1.828 & 2.220 \\
\hline
\end{tabular}

BW, body weight; DG, daily gain; DFI, daily feed intake; FCR, feed conversion ratio; Mor., mortality.

Table 4 - Effect of nPP levels and phytase supplementation on performance and bone characteristics of broiler chicks from 21 to $36 \mathrm{~d}$ fed corn-soybean meal based diet.

\begin{tabular}{|c|c|c|c|c|c|c|c|c|c|c|c|c|}
\hline \multirow[t]{2}{*}{ NPP (\%) } & \multirow{2}{*}{$\begin{array}{l}\text { Phytase } \\
\text { (F.T.U./kg) }\end{array}$} & \multirow{2}{*}{$\begin{array}{l}\text { BW, g } \\
(36 \text { d) }\end{array}$} & \multirow[t]{2}{*}{ DG, $\mathbf{g}$} & \multirow[t]{2}{*}{ DFI, $g$} & \multirow{2}{*}{$\begin{array}{l}\text { FCR } \\
(g / g)\end{array}$} & \multirow{2}{*}{$\begin{array}{l}\text { Toe ash } \\
\text { (\%) }\end{array}$} & \multirow{2}{*}{$\begin{array}{c}\text { Shank } \\
\text { length }(\mathrm{mm})\end{array}$} & \multicolumn{2}{|c|}{ Tibia } & \multicolumn{2}{|c|}{ Femur } & \multirow[b]{2}{*}{$\begin{array}{l}\text { Mor. } \\
(\mathrm{mm})\end{array}$} \\
\hline & & & & & & & & $\begin{array}{l}\text { Length } \\
(\%)\end{array}$ & $\begin{array}{l}\text { Ash } \\
\text { (\%) }\end{array}$ & $\begin{array}{l}\text { Length } \\
(\%)\end{array}$ & $\begin{array}{l}\text { Ash } \\
(\%)\end{array}$ & \\
\hline 0.414 & 0 & $1640 \mathrm{ab}$ & $65.7 a$ & $133.2 \mathrm{ab}$ & $2.03 b c$ & $13.3 a$ & $78.7 a$ & $95.4 a$ & $31.4 a$ & $71.9 a$ & $40.0 a$ & $5.1 d$ \\
\hline 0.364 & & $1712 a$ & $68.1 \mathrm{a}$ & $136.2 a$ & $2.00 \mathrm{bc}$ & $13.2 \mathrm{a}$ & $77.2 \mathrm{a}$ & $97.6 a$ & $30.5 \mathrm{ab}$ & $72.3 a$ & $39.8 a$ & $6.5 d$ \\
\hline 0.314 & & $1557 b$ & $63.3 a$ & $124.5 b$ & $1.97 \mathrm{c}$ & $12.6 a$ & $75.0 \mathrm{ab}$ & $92.3 a$ & $30.0 a b$ & $69.4 a$ & $33.1 b$ & $5.1 d$ \\
\hline 0.264 & & $1329 c$ & $51.6 b$ & $111.3 \mathrm{c}$ & $2.17 b$ & $11.1 \mathrm{~b}$ & $74.5 \mathrm{ab}$ & $91.8 \mathrm{a}$ & $28.6 \mathrm{bc}$ & $68.8 a$ & $32.5 b$ & $10.0 \mathrm{dc}$ \\
\hline 0.214 & & $1051 \mathrm{de}$ & $36.1 \mathrm{dc}$ & $76.3 \mathrm{e}$ & $2.12 \mathrm{bc}$ & $10.8 b$ & $69.2 b c$ & $85.2 b$ & $26.1 \mathrm{~d}$ & $60.3 b$ & $28.5 b$ & $19.2 b$ \\
\hline 0.164 & & $928 \mathrm{e}$ & $31.2 d$ & $73.7 \mathrm{e}$ & $2.36 a$ & $8.8 c$ & $65.1 \mathrm{c}$ & $82.7 b$ & $24.7 d$ & $58.5 b$ & $27.6 b$ & $39.9 a$ \\
\hline 0.164 & 500 & $1100 d$ & $41.3 c$ & $86.9 d$ & $2.11 \mathrm{bc}$ & $9.7 \mathrm{bc}$ & $63.3 c$ & $82.5 b$ & $27.8 \mathrm{~cd}$ & $62.6 b$ & $33.0 \mathrm{~b}$ & $13.2 b c$ \\
\hline P-value & & 0.0001 & 0.0001 & 0.0001 & 0.0017 & 0.0001 & 0.0001 & 0.0001 & 0.0001 & 0.0001 & 0.0001 & 0.0001 \\
\hline SEM & & 43.648 & 1.781 & 3.416 & 0.057 & 0.465 & 2.130 & 2.072 & 0.751 & 1.572 & 1.274 & 2.334 \\
\hline
\end{tabular}

Table 5 - Effect of nPP levels and phytase supplementation on performance and bone characteristics of broiler chicks from 0 to $36 \mathrm{~d}$ fed corn-soybean meal based diet.

\begin{tabular}{|c|c|c|c|c|c|c|}
\hline \multicolumn{2}{|c|}{ NPP (\%) } & \multirow{2}{*}{\begin{tabular}{|c|} 
Phytase \\
(F.T.U./kg)
\end{tabular}} & \multirow{2}{*}{$\begin{array}{c}\text { DG, } \\
\mathbf{g}\end{array}$} & \multirow{2}{*}{$\begin{array}{c}\text { DFI, } \\
\mathbf{g}\end{array}$} & \multirow{2}{*}{$\begin{array}{c}\text { FCR } \\
(g / g)\end{array}$} & \multirow{2}{*}{$\begin{array}{l}\text { Mor. } \\
\text { (\%) }\end{array}$} \\
\hline $0-20 d$ & $21-36 d$ & & & & & \\
\hline 0.45 & 0.414 & 0 & $44.6 a b$ & $85.2 a$ & $1.91 \mathrm{C}$ & $10.7 d$ \\
\hline 0.40 & 0.364 & & $46.1 \mathrm{a}$ & $87.1 a$ & $1.89 c$ & $13.1 d$ \\
\hline 0.35 & 0.314 & & $42.2 b$ & $78.8 b$ & $1.87 \mathrm{c}$ & $10.7 d$ \\
\hline 0.30 & 0.264 & & $35.5 c$ & $71.1 \mathrm{c}$ & $2.01 \mathrm{bc}$ & $14.3 d c$ \\
\hline 0.25 & 0.214 & & $26.1 d$ & $55.9 d$ & $2.14 b$ & $25.0 \mathrm{~b}$ \\
\hline 0.20 & 0.164 & & $19.5 e$ & $50.3 e$ & $2.56 a$ & $54.8 a$ \\
\hline 0.20 & 0.164 & 500 & $28.3 d$ & $60.7 d$ & $2.15 b$ & $21.4 b c$ \\
\hline$P$-value & & & 0.0001 & 0.0001 & 0.0001 & 0.0001 \\
\hline SEM & & & 0.918 & 1.753 & 0.054 & 2.800 \\
\hline
\end{tabular}

Whilst feeding a diet containing $0.314 \%$ of nPP was enough to sustain toe and tibia ash (\%, Table 4), a higher nPP level was required to maintain femur ash content $(0.364 \%)$ as compared to the control. Bone length data showed that less nPP was required to support the length of different leg segments $(0.264 \% \mathrm{nPP})$ as compared to ash. Nonlinear regression estimates of the nPP requirement between 21 and 36d (Table 9) also showed that, as compared to 0 to $20 \mathrm{~d}$, less nPP was required to maintain BW, DG, DFl, and bone characteristics. However, the amount of nPP (\%) required for optimal FCR and bird survival remained approximately at the same level during the 0 to $20 \mathrm{~d}$ growth period.

Pearson correlation analysis (Table 6, 21 to 36d) also showed highly significant positive correlations 
Karimi A, Bedford MR, Sadeghi Gh, Ghobadi Z

Table 6 - Correlation (Pearson) coefficients matrix between nPP level and performance \& bone parameters.

\begin{tabular}{|l|c|c|c|c|}
\hline \multirow{2}{*}{ Criteria } & \multicolumn{2}{|c|}{ 0 to 20 d } & 21 to 36 d & \multirow{2}{*}{ p-value } \\
\cline { 2 - 4 } & Coefficient & p-value & Coefficient & \\
\hline Performance & \multicolumn{4}{|l}{} \\
\hline BW, g & 0.9355 & 0.0001 & 0.9253 & 0.0001 \\
\hline DG, g & 0.9355 & 0.0001 & 0.9262 & 0.0001 \\
\hline DFI, g & 0.8183 & 0.0001 & 0.9202 & 0.0001 \\
\hline FCR, g.g-1 & -0.8096 & 0.0001 & -0.6398 & 0.0008 \\
\hline Mor. & -0.5771 & 0.0003 & -0.8066 & 0.0001 \\
\hline
\end{tabular}

Bone ash, \%

\begin{tabular}{|l|c|c|c|c|}
\hline Toe & - & & 0.8461 & 0.0001 \\
\hline Femur & 0.8727 & 0.0001 & 0.9146 & 0.0001 \\
\hline Tibia & 0.8789 & 0.0001 & 0.8794 & 0.0001 \\
\hline
\end{tabular}

Bone length, mm

\begin{tabular}{|l|c|c|c|c|}
\hline Femur & 0.8883 & 0.0001 & 0.8621 & 0.0001 \\
\hline Tibia & 0.8242 & 0.0001 & 0.7972 & 0.0001 \\
\hline Shank & 0.7817 & 0.0001 & 0.7663 & 0.0001 \\
\hline Blood serum P & 0.6750 & 0.0003 & - & \\
\hline
\end{tabular}

BW, body weight; DG, daily gain; DFI, daily feed intake; FCR, feed conversion ratio; Mor, mortality.

between dietary nPP level and most measured traits and a negative correlation between dietary nPP and FCR and mortality rate.

Dietary nPP levels had significant effects on DG, DFI, FCR and mortality rate (\%) over the whole study
Influence of Dietary Non-phytate Phosphorous Levels and Phytase Supplementation on the Performance and Bone Characteristics of Broilers

period (Table 5). Chicks fed diets containing $0.40 \%$ nPP between 1 to $21 \mathrm{~d}$, and $0.364 \%$ nPP between 21 to $36 d$ had the best $(p<0.05) D G$ and DFI. Feeding diets containing lower levels of nPP $(0.25$ and $0.214 \%$ during 0 to $20 \mathrm{~d}$ and 21 to $36 \mathrm{~d}$, respectively) was adequate to minimize total mortality rate and FCR.

The fact that reducing $\mathrm{nPP}$ levels during the starter period to $0.40 \%$ did not adversely affect broiler performance, but further reduction to less than 0.35 $\%$ did, indicates that the broiler's requirement for phosphorus is lower than current recommendations. Data from literature on nPP requirements during the various growth periods is equivocal, with some papers suggesting lower nPP levels than those recommended by the NRC (1994) are required to constrain growth (Sohail \& Roland, 1999; Waldroup, 1999) and others suggesting these levels are already deficient (NRC, 1994).

The results of the present experiment also indicated that the bird's response to dietary nPP levels depends on growth phase (starter vs. grower) and the criteria used as an indicator of phosphorus adequacy. These finding are also consistent with the results reported on nPP requirements of broiler chicks in the finisher and withdrawal periods (NRC, 1994; Waldroup, 1999), in which $P$ requirements of broilers decrease with age. This is partly due to an age-related increase in feed intake, but also to the maturation of skeletal systems and thus reduced $P$ requirements for bone mineralization.

Table 7 - Calculated phosphorus releasing ability (equivalency) of phytase using different performance and bone parameters as assessment criterion.

\begin{tabular}{|c|c|c|c|c|c|c|c|c|}
\hline \multirow[t]{2}{*}{ Criteria } & \multicolumn{4}{|c|}{0 to $20 \mathrm{~d}$} & \multicolumn{4}{|c|}{21 to $36 \mathrm{~d}$} \\
\hline & Linear & Logarithmic & Quadratic & Average & Linear & Logarithmic & Quadratic & Average \\
\hline \multicolumn{9}{|l|}{ Performance } \\
\hline BW & 0.06 & 0.06 & 0.06 & 0.060 & 0.04 & 0.04 & 0.04 & 0.040 \\
\hline $\mathrm{DG}$ & 0.06 & 0.06 & 0.05 & 0.057 & 0.05 & 0.05 & 0.05 & 0.050 \\
\hline DFI & 0.10 & 0.09 & 0.10 & 0.097 & 0.05 & 0.04 & 0.04 & 0.040 \\
\hline $\mathrm{FCR}$ & 0.04 & 0.04 & 0.04 & 0.040 & 0.12 & 0.12 & 0.09 & 0.110 \\
\hline Mor. & 0.12 & 0.12 & 0.08 & 0.107 & 0.13 & 0.12 & 0.09 & 0.110 \\
\hline \multicolumn{9}{|l|}{ Bone ash, \% } \\
\hline Toe & - & - & - & - & 0.03 & 0.03 & 0.03 & 0.030 \\
\hline Femur & 0.06 & 0.06 & 0.07 & 0.063 & 0.11 & 0.11 & 0.11 & 0.110 \\
\hline Tibia & 0.04 & 0.04 & 0.04 & 0.040 & 0.05 & 0.05 & 0.04 & 0.047 \\
\hline \multicolumn{9}{|c|}{ Bone length, mm } \\
\hline Femur & 0.04 & 0.04 & 0.04 & 0.040 & 0.05 & 0.06 & 0.06 & 0.057 \\
\hline Tibia & 0.04 & 0.04 & 0.04 & 0.040 & 0.00 & 0.00 & 0.01 & 0.003 \\
\hline Shank & 0.05 & 0.05 & 0.05 & 0.050 & 0.00 & 0.00 & 0.00 & 0.000 \\
\hline Blood serum $P$ & 0.09 & 0.08 & 0.11 & 0.093 & - & - & - & - \\
\hline
\end{tabular}


Table 8 - Nonlinear regression estimate of nPP requirements of broiler chicks from 0 to $20 \mathrm{~d}$.

\begin{tabular}{|c|c|c|c|c|}
\hline & Inflection point $^{1}$ & Value at inflection & Asymptotic standard error & Asymptotic $95 \%$ confidence interval \\
\hline \multicolumn{5}{|l|}{ Performance } \\
\hline BW at $20 \mathrm{~d}, \mathrm{~g}$ & 0.3806 & 619.0 & 0.0105 & $0.3587-0.4025$ \\
\hline$D G, g$ & 0.3745 & 29.03 & 0.0093 & $0.3551-0.3939$ \\
\hline $\mathrm{DFl}, \mathrm{g}$ & 0.4040 & 48.59 & 0.0345 & $0.3323-0.4757$ \\
\hline$F C R, g: g$ & 0.3076 & 1.70 & 0.0084 & $0.2901-0.3251$ \\
\hline Mor., \% & 0.2667 & 5.95 & 0.0206 & $0.2239-0.3095$ \\
\hline \multicolumn{5}{|l|}{ Bone ash, \% } \\
\hline Femur & 0.4793 & 39.23 & & . \\
\hline Tibia & 0.4102 & 36.47 & 0.0274 & $0.3532-0.4672$ \\
\hline \multicolumn{5}{|c|}{ Bone length, mm } \\
\hline Femur & 0.3879 & 52.14 & 0.0282 & $0.3297-0.4466$ \\
\hline Tibia & 0.4482 & 68.81 & 0.0450 & $0.3546-0.5418$ \\
\hline Shank & 0.4443 & 54.53 & 0.0511 & $0.3381-0.5506$ \\
\hline Serum P level, & 0.3208 & 4.70 & 0.0525 & $0.2112-0.4304$ \\
\hline
\end{tabular}

Table 9 - Nonlinear regression estimate of nPP requirements of broiler chicks from 21 to $36 \mathrm{~d}$

\begin{tabular}{|c|c|c|c|c|}
\hline & Inflection point $^{1}$ & Value at inflection & Asymptotic standard error & Asymptotic $95 \%$ confidence interval \\
\hline \multicolumn{5}{|l|}{ Performance } \\
\hline BW at $36 \mathrm{~d}, \mathrm{~g}$ & 0.3452 & 1675.80 & 0.0129 & $0.3184-0.3720$ \\
\hline DG, g & 0.3344 & 66.91 & 0.0103 & $0.3131-0.3558$ \\
\hline $\mathrm{DFl}, \mathrm{g}$ & 0.3413 & 134.70 & 0.0138 & $0.3126-0.3699$ \\
\hline$F C R, g: g$ & 0.3140 & 2.00 & 0.0492 & $0.2116-0.4164$ \\
\hline Mor., \% & 0.2725 & 5.53 & 0.0097 & $0.2524-0.2927$ \\
\hline \multicolumn{5}{|l|}{ Bone ash, $\%$} \\
\hline Toe & 0.3429 & 13.26 & 0.0256 & $0.2896-0.3963$ \\
\hline Femur & 0.3798 & 40.01 & 0.0230 & $0.3319-0.4277$ \\
\hline Tibia & 0.3759 & 31.44 & 0.0277 & $0.3182-0.4336$ \\
\hline \multicolumn{5}{|c|}{ Bone Length, $\mathrm{mm}$} \\
\hline Femur & 0.3344 & 72.07 & 0.0202 & $0.2924-0.3764$ \\
\hline Tibia & 0.3589 & 96.49 & 0.0358 & $0.2842-0.4334$ \\
\hline Shank & 0.3723 & 78.70 & 0.0428 & $0.2833-0.4613$ \\
\hline
\end{tabular}

Similar results were reported by Sohail \& Roland (1999), in which neither performance nor bone strength was significantly influenced as a result of nPP reduction from 0.425 to $0.325 \%$ nPP fed to 3-to-6 wk broiler chicks, further supporting lower nPP requirements for broilers than those currently suggested by the NRC (1994). The current results suggest that feeding $0.40 \%$ followed by $0.35 \% \mathrm{nPP}$ diets during starter and grower periods respectively results in sufficient retainable phosphorus to support optimal live weight and feed intake, with such levels actually being in excess of that required for maintaining feed conversion ratio or mortality rate comparable to controls.

The higher sensitivity of the femur as compared to the shank and tibia to reduced nPP levels mirrors the degree of maturation of these bones at the ages investigated. It also suggests that the selection of specific bones as indicators of bone development should take into account the age of the bird at the time of sampling. It is clearly of interest to ensure that the bone selected is still growing and mineralising to maximise the likelihood of detecting differences between treatments. 


\section{Phytase effect}

The results of the present experiment suggest that between 0 and $20 \mathrm{~d}$, the addition of 500 F.T.U. of phytase to the nPP deficient diet $(0.20 \% \mathrm{nPP})$ significantly $(p<0.05)$ improved BW, DG, DFI and FCR, and decreased mortality rate (Table 3 ). However, the effects on plasma P level, bone length, and ash content were not significant ( $p>0.05$ ). The addition of 500 F.T.U. of phytase to the diet between 21 and 36 d significantly $(p<0.05)$ improved BW, DG, DFI, FCR, mortality rate, tibia and femur ash weights, but the effects on toe ash (\%), shank length, tibia and femur lengths, and ash percentage were not significant ( $>0.05$ ) as compared to the control treatment (Table 4). Over the whole experimental period the addition of phytase significantly $(p<0.05)$ improved DG, DFI, FCR, and decreased morality rate (Table 5 ).

The $P$ equivalency of the phytase (500 F.T.U./ $\mathrm{kg}$ ) was estimated using linear, logarithmic, and quadratic equations linking dietary nPP level with each performance and bone parameters of interest. Estimates of phosphorus equivalency of the phytase treatment (Table 7) varied and were dependent on the performance or bone characteristic used as the criterion for assessment. For example, during the 0 to $20 \mathrm{~d}$ growth period, whilst the phosphorus equivalency of phytase ranged between 0.04 and 0.06 when BW, DG and FCR, respectively, were used as assessment criteria, it increased to approximately $0.10 \%$ when DFI or mortality rate were considered. Furthermore, $\mathrm{P}$ equivalency of phytase for some variables such as DFI, $F C R$, and femur ash changed with age (some reducing and some increasing with age); for the remaining variables these values remained relatively constant.

The beneficial effects of phytase on broiler chicks have been reported previously by many researchers. Sohail \& Roland (1999) observed that when the nPP level of diets fed to broiler chicks between 4-6 wk of age were set at $3.30 \mathrm{~g} \mathrm{~kg}^{-1}$, there was little, if any, positive effect of added phytase on performance. The response to phytase became significant at lower nPP levels $\left(2.25 \mathrm{~g} \mathrm{~kg}^{-1}\right)$. Low nPP diets typically result in reduced gain and feed intake and sometimes there is a mildly adverse effect on FCR. Performance is often restored with the addition of phytase (Simons et al., 1990; Sohail \& Roland, 1999; Yan et al., 2001; Punna \& Roland, 2001; Ravindran et al., 2001; Lan et al., 2002; Viveros et al., 2002; Yan et al., 2003; Shirley \& Edwards, 2003; Karimi, 2006), provided the initial deficiency was not too severe and the addition rates of phytase were adequate.
The multifaceted effects of phytase in practical diets are increasingly appreciated. It is possible that the observed performance response may reflect the release of $\mathrm{P}$, available amino acids, and energy, alone or in combination. Generally, an improvement of 1.5 to 3.0 percentage points in performance was often observed in piglets and broilers when phytase was included in the diet, even when the diet met the digestible/available $\mathrm{P}$ requirement (Kies et al., 2001), suggesting significant extra-phosphoric effects of this enzyme. Nevertheless, the response of broilers to phytase is still not predictable, because there are many factors, including, concentration and source of phytin, protein quality, concentrations of divalent cations, vitamin $\mathrm{D}$, mineral chelators in the diet, along with animal factors such as species, genetics and sex, and even diet processing, that may potentially affect the bird's response to dietary phytase supplementation (Kies et al., 2001; Adeola \& Sands, 2003). The findings of this experiment indicate that the scale of the positive effect of phytase for broilers varies and is very much dependent upon the age and assessment criterion employed. Caution is therefore needed when utilising a phytase product, and it must be taken into account that $P$ equivalency of a phytase is not a constant that can be used in practical diet formulation.

In conclusion, the results of this experiment showed that feeding low nPP diets reduced bird performance and bone mineralization; however, the response to nPP level is not constant and depends on the measured trait and/or bird age. In addition, though supplementation of phytase is effective in offsetting at least some of the negative effects of lowering dietary nPP level, caution must be taken when setting rigid $\mathrm{P}$ equivalency values for a phytase product in practical diet formulation. Despite the numerous studies that have been undertaken to assess the effectiveness of phytase in broiler nutrition, more research is needed to determine more accurately $P$ equivalency of phytase under different nutritional and management practices.

\section{REFERENCES}

Adeola O, Sands JS. Does supplemental dietary microbial phytase improve amino acid utilization? A perspective that it does not. Journal of Animal Science 2003; 81(E Suppl 2):E78- E85.

AOAC. Official methods of analysis. 15th ed. Arlington: Association of Official Analytical Chemists; 1990.

Bedford MR. Exogenous enzymes in monogastric nutrition-their current value and future benefits. Animal Feed Science and Technology 2000; 86:1-13. 
Correll D. Phosphorus: a rate limiting nutrient in surface waters. Poultry Science 1999; 78:674-682.

Karimi A. Responses of broiler chicks to non-phytate phosphorus levels and phytase supplementation. International Journal of Poultry Science 2006; 5:251-254.

Kies AK, Van Hemert KHF, Sauer WC. Effect of phytase on protein and amino acid digestibility and energy utilisation. World's Poultry Science Journal 2001; 57:109-126.

Kilburn J, Edwards Jr HM. The response of broilers to the feeding of mash or pelleted diets containing maize of varying particle sizes. British Poultry Science 2001; 42:484-492.

Lan GQ, Abdullah N, Jalaludin S, Ho YW. Efficacy of supplementation of a phytase-producing bacterial culture on the performance and nutrient use of broiler chickens fed corn-soybean meal diets. Poultry Science 2002; 81:1522-1532.

NRC. Nutrient requirements of poultry. Nutrient requirements of domestic animals. 9th ed. Washington: National Academy Press; 1994.

Olukosi OA, Cowieson AJ, Adeola O. Age-related influence of a cocktail of xylanase, amylase, and protease or phytase individually or in combination in broilers. Poultry Science 2007; 86:77-86.

Olukosi OA, Cowieson AJ, Adeola O. Energy utilization and growth performance of broilers receiving diets supplemented with enzymes containing carbohydrase or phytase activity individually or in combination. British Journal of Nutrition 2008; 99:682-690.

Powell S, Johnston S, Gaston L, Southern LL. The effect of dietary phosphorus level and phytase supplementation on growth performance, bone-breaking strength, and litter phosphorus concentration in broilers. Poultry Science 2008; 87:949-957.

Punna S, Roland Sr DA. Influence of dietary phytase supplementation on incidence and severity in broilers divergently selected for tibial dyschondroplasia. Poultry Science 2001; 80:735-740.

Ravindran V, Selle PH, Ravindran G, Morel PCH, Kies AK, Bryden WL. Microbial phytase improves performance, apparent metabolizable energy, and ileal amino acid digestibility of broilers fed a lysinedeficient diet. Poultry Science 2001; 80:338-344.

Robbins KR, Norton HW, Baker DH. Estimation of nutrient requirements from growth data. Journal of Nutrition 1979; 109: 1710-1714.

Robbins KR. A method, SAS program, and example for fitting the broken-line to growth data. Greeneville: University of Tennessee Agricultural Experiment Station Research Report; 1986. p.89.

SAS Institute. SAS ${ }^{\circledR}$ User's guide: statistics, Version 6.03 edn. Cary: SAS Institute; 1991.

Selle PH, Ravindran V, Bryden WL, Scott T. Influence of dietary phytate and exogenous phytase on amino acid digestibility in Poultry: A review. The Journal of Poultry Science 2006; 43:89-103.

Shirley RB, Edwards Jr HM. Graded levels of phytase past industry standards improves broiler performance. Poultry Science 2003; 82: 671-680.

Simons PCM, Versteegh HAJ, Jongbloed AW, Kemme PA, Slump $P$, Bos KD, Wolters MGE, Beudeker RF, Verschoor GJ. Improvement of phosphorus availability by microbial phytase in broilers and pigs. British Journal of Nutrition 1990; 64:525-540.

Sohail SS, Roland Sr DA. Influence of supplemental phytase on performance of broilers four to six weeks of age. Poultry Science 1999; 78:550-555.

Summers JD. Precision phosphorus nutrition. The Journal of Applied Poultry Research 1997; 6:495-500.

Viveros A, Brenes A, Arija I, Centeno C. Effects of microbial phytase supplementation on mineral utilization and serum enzyme activities in broiler chicks fed different levels of phosphorus. Poultry Science 2002; 81:1172-1183.

Waldroup P. Nutritional approaches to reducing phosphorus excretion by poultry. Poultry Science 1999; 78:683-691.

Yan F, Kersey JH, Fritts CA, Waldroup PW. Phosphorus requirements of broiler chicks six to nine weeks of age as influenced by phytase supplementation. Poultry Science 2003; 82:294-300.

Yan F, Kersey J, Waldroup PW. Phosphorus requirements of broiler chicks three to six weeks of age as influenced by phytase supplementation. Poultry Science 2001; 80:455-459.

Yan F, Waldroup PW. Nonphytate phosphorus requirement and phosphorus excretion of broiler chicks fed diets composed of normal or high available phosphate corn as influenced by phytase supplementation and vitamin D source. International Journal of Poultry Science 2006; 5: 683-228. 